\title{
Using Top and Tail Game to Improve Students' Vocabulary Mastery
}

\author{
Yovita Dyah Permatasari \\ Institut Agama Islam Al- Falah Assunniyyah Kencong \\ (yovita.aza@gmail.com)
}

\begin{abstract}
The aimed of this study was to show the empirical evidence about the improvement of the students' vocabulary mastery through Top and Tail Game at the eighth grade students of MTs Negeri 1 Sumberbaru in 2018/2019 academic year. The subject of this study was VIII students of MTs Negeri 1 Sumberbaru. The research method is used classroom action research (CAR) which follows the design of Kurt Lewin. This research was conducted in two cycles. This research was carried out for one month. Techniques of data collection were interviews, observation, and test. The findings of the research showed that, the firs cycle has not achieved the criteria of success, which is the mean of 70 . It was reflected that the students' response were not observable yet when being taught by using Top and Tail Game as a new media in vocabulary. Moreover, the teacher has difficulties in teaching vocabulary by using Top and Tail Game. In the second cycle, the criteria of success was achieved. The result of this study was the implementation of learning English vocabulary through top and tail game has increased. Based on the result, it can be concluded that using top and tail game at the eighth grade students of MTs Negeri 1 Sumberbaru can improve students' vocabulary mastery. The result of this research shows that there is an improvement in students' vocabulary mastery.
\end{abstract}

Keywords: Top and tail game; vocabulary mastery.

English is essential to be taught for students from the primary level to senior high school. In senior high school, English is taught as the first foreign language. English covers four skills; listening, reading, speaking and writing. There is a basic component taught at the first grade of senior high school, this component is the vocabulary. This is one important component in foreign language learning. As Cameron (2001, p.72) states that building up as useful vocabulary is central to the learning of a foreign language at primary level. With vocabulary, learners can learn how to communicate and transfer their ideas through simple expressions. Thornbury (2002, p.13) adds up that without grammar little 
things can be conveyed, without vocabulary nothing can be conveyed. This statement urges how important it is vocabulary in learning a language. Thus, vocabulary is an essential part of language, which makes the language meaningful. Vocabulary should be mastered in any language learning not to mention English. According to Kridalaksana (2008, p.142) vocabulary represent: (1) Language component claiming all information about meaning and word usage 2) vocabulary mastery of the speaker or writer of a language. This statement, again strengthen the essential of vocabulary in language learning. It helps learners convey and understand information.

Vocabulary is the basic component to have communication, if the students do not recognize the meaning of the key words used in an interaction; they will not be able to participate actively in the conversation. English teachers must have something to help learners with their vocabulary mastery. For example, by using teaching techniques or using interesting educational media to attract the students during the learning process. Agoestyowati (2007, p.22) says that learning a new language should be fun, interactive and exciting. The use of game in learning will not only change the dynamic of the class, but it will also rejuvenate students and help the brain to learn more effectively. Having interesting and appropriate teaching aids can help teachers to deliver the lesson more effectively and efficiently. As a result, it will help learners learn better and gain better understanding.

Vocabulary is an important element in learning English. Through vocabulary, people will know what other people talk about. Harmer (2001, p.154) urges vocabulary includes the meaning of words, their lexical grammar, and collection rules. This means, through vocabulary, a person can convey his intentions through words meaning and it will also help him to be familiar with the lexical grammar or the patterns employed in a language so that he will gradually recognize the rules he need to follow when using the language. Vocabulary helps learners with the skills of the learned language. The more vocabulary one knows, the better he will be to convey his ideas, orally through spoken interaction or in written. This is in line with Hornby (2000, p.959) statement that vocabulary is a total number of words with the rules for combining them to make up the language. This implies that vocabulary assist learners to be familiar with rules of a language.

Students are having a very low retention in their memory with the vocabulary of the foreign language they learn. This has led to the situation that they could not speak English well because of limited vocabulary, thus the students were not interested in learning English. The phenomenon also occurred in the school the writer has for her study; from 39 students of $8 \mathrm{~B}$, only 3 students got good scores criteria of minimum mastery 70 (KKM), and the others got under criteria of minimum mastery. It means that the students who got difficulties with the vocabulary were 36 students. To dig up learner's interest, a strategy is required. One of the ways is by having a game in the learning. As Wright (2006,p.1) mentions that games help teachers create context in which the language can useful and meaningful. This is supported by Gordon $(1999$, p.5) that games are fun. It means that games are enjoyable and able to encourage students' motivation in learning. Teachers apply games in the learning because they have an intention to attract and motivate the students in learning foreign language in order to get them acquired skills in using the language.

One of the games used in vocabulary learning is called as Top and tail. It is a game in which the students have to create a word from the last letter of word that was mentioned by the students. The aim of top and tail game is to enable the students to enrich their vocabulary. The game is applicable for all levels of learners. The teacher can develop this game by asking the students to give the meaning of those words and put it into sentences. This game also helps to improve and increase their vocabulary. The advantages of top and tail game are to bring in relaxation and fun for students thus help them 
learn and retain new words more easily. This game usually involves friendly competition and they keep learners interested. And these created the motivation for learners of English to get involved and participate actively in the learning activities, bring real world context into the classroom, and motivate the students to use in communication.

\section{Method}

The method used in this research was classroom action research (CAR). The subject of this research was the students at the eighth grade of Mts Negeri 1 Sumberbaru (VIIIB) consisted of 39 students. The Classroom Action Research (CAR) procedure used in this research was Kurt Lewin's Design. It was used because Lewin's design was more comprehensible and understandable for the writer. However, later the writer developed the design from Lewin. There are four phases in each cycle; planning, acting, observing, and reflecting (Arikunto, 2009, p. 130). In this research, the writer implemented two cycles.

This research was conducted in MTs Negeri 1 Sumberbaru. The subject of this research was the students of eighth grade of Mts Negeri 1 Sumberbaru. The writer acted as the real teacher, while the real teacher acted as the observer. The problem of this class was the students were not active in teaching learning process, and also they had lowest average score than the other class.

In collecting data, the instrument that the writer used are observation, test, and interview. In addition, through observation, the teacher could observe implicit understanding and how theory in use. Then, the interview is used as an additional way in gaining deeper information about something. Then, the test is to measure the students' vocabulary score. The analysis qualitative data used in this study is the observation of students' activities during teaching- learning process, and the interview before and after CAR. Then, in analysis the quantitative data which is test, the writer took the average of students' vocabulary score in one cycle. It is used to measure how well students' ability on vocabulary.

\section{Results and Discussion}

This research was conducted in six meetings. The first, second, and third meetings were cycle 1 . This was used to test the model which has been developed. The fourth, fifth, and sixth meetings were cycle 2 . The cycle 2 was used to test the model which has been revised by the writer from the reflection of cycle 1 . In the first meeting the researcher gave a preliminary test to know their vocabulary mastery before doing the action. The result of pre-test shows that 3 students (7.6\%) got good criteria and 36 students ( $92.4 \%$ ) got poor criteria. It showed that most of the students got poor criteria, and only three students (7.6\%) who had reached the standard score. It happened because their vocabulary was limited, so they could not answer the test correctly. It also caused by the students who were confused of writing the meaning of the words in English. It is seen from the students' result score. The Pie Chart in Figure 1 shows the results.

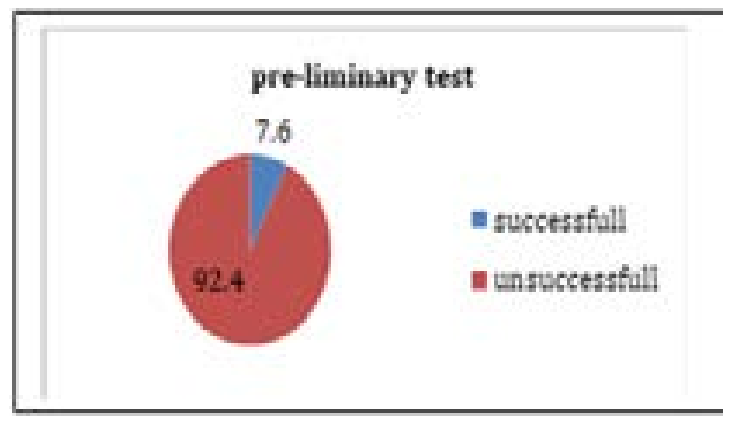

Figure 1. Pie Chart of Research Result

The average post-test score for both experimental classes were 72,1 and 72,4 while the controlled class was 68,2 . So, the writer was successful in doing the research because there was a significant improvement for both experimental classes than controlled class.

In the first meeting, the observer (the English teacher of Mts Negeri 1 Sumberbaru realized that the teacher (the writer) had to do 
a lot of effort to make or to change the students' attitude toward English. Some of them were quite active and enthusiasm with the teacher and followed the instructions given by her. However, some of them were quite hard to work with, they tend to make some noise to distract other students. So, the teacher gave some rules for anyone who disturbed or did not follow the instruction from the teacher to make the class became effective for both in teaching and learning process.

In the second meeting, the observer watched a better classroom condition; they did not make a lot of noise because of that 'rules'. It was quite effective to them. They were noises when they played top and tail game, they asked a lot questions about the rules and the teacher answered them patiently. The game was the first to them. As the result, some of students were confused and nervous about the game but the rest of them were interested and anticipated. In the middle of the game, they still did not get it when they played the game, some of the students even mismatched with how to continued the vocabulary with top and tail game. So, it was messed up for moment. Fortunately, there was a student who kindly help to explain about the rules one more time to other students. It was relieved because the situation was under control and the student's help was really helped for teacher. Then, the students continued to play the game for the rest of the time.

In the third meeting, the observer watched the class was in a good mood condition, the students anticipated about the new material from the teacher and also the game. So, the second time game was given, the students still asked several questions regarding the game but that was quite better because they were slowly understood about how to play the game. The students followed and enjoyed the activities in the class. In here, the teacher orally test to the students by making an English Word (visit), and then ask another student to make a word beginning with $\mathrm{T}$ (the last letter of the previous word), example 'Take' then the next student must make a word beginning with $\mathrm{E}$, until one of students cannot think a word or mention a word already said. They often made a mistake about the mismatch of each student and that what made the game seemed alive and fun. In the fourth meeting, the teacher performance was really excellent, because she gave a real thing or sample to the students, so that the students connected with the material easily. Degree of comparison is quite complicated because in different degree there was some changing in the words but the clear explanation from the teacher made it easy to understand. When they played top and tail game, the students finally understood with the rule and how to play the game. The teacher here developed the game, for example the students here divided into several group, it was six students each group and they had to face another group to become a winner in the class. In five minutes, they had to mention the words many as possible. As the result, in this meeting the lesson plan was run well and also the students' response were excited and joyful because there was a competitive situation to make them became more responsible in doing the game.

The fifth meeting, the new material was given to the students which was advertisement text. Overall, the students' participation was quite better than the previous cycle. They were brave to ask and answer the questions from the teacher. In the learning process, they remained silent and kept attention to the teacher and when the teacher gave the assignment about making a poster about advertisement text, they were so excited because their hidden talent finally rose up, some of students were like to draw and paint. So, the students did it with a happy feeling when they made it.

In the sixth meeting, the teacher asked the students to present their poster in front of the class. It was a big thing for them because they rare to speak or perform in front of the class. In here, in order to avoid their shyness and nervous, each group performed together in front of the class. However, the outcome was 
not good because the class was super noisy but then the teacher acted soon with giving some rules for both speaker and listener and later the condition of the class became more effective.

After conducting two cycles in this research, the result of the vocabulary test indicated that top and tail game could improve the students' vocabulary mastery. Top and tail game never used by the English teacher in MTs JauharotulMu'aliminGayauSakti as a media in teaching and learning process. By using Top and tail game, will make the students easier to study English especially in studying vocabulary. They were able to memorizing easier the vocabulary with this game.

Top and tail game is fun. When the students feel fun in learning, they will have strong motivation to learn. This also supported by Uberman (1998) who said that games offer students a fun-filled and relaxing learning atmosphere. After learning and practicing new vocabulary, students had the opportunity to use language in a non-stressful way. This can be seen from the result of the shy students' activity in classroom. By using top and tail game, slow but sure the shy students became more active and brave to express their idea.

As the finding of this research, the researcher have made a model in order to use top and tail game in improving students' vocabulary mastery, as seen in Table 1.

This is the final model which has been used by the researcher in her research. By implementing this model, not only can improve students' vocabulary mastery but also can improve students activity during teaching learning process. In the teaching learning process, the students should more active than the teacher. The teachers' duty was as helper who helps the students if they have any difficulties in following the teaching learning process.

\section{Conclusion}

Based on the research finding and analyzing the data in the process of teaching vocabulary by using top and tail game at the eighth grade students of MTs Negeri 1 Sumberbaru academic year 2018/ 2019

Table 1. Proposed model of Top and Tail Game

\begin{tabular}{|c|c|c|}
\hline \multirow[t]{2}{*}{ Steps } & \multicolumn{2}{|c|}{ Activity } \\
\hline & Students & Teacher \\
\hline Introducing & $\begin{array}{l}\text { The students are introduced about top } \\
\text { and tail game. Propose examples of top } \\
\text { and tail game in their mother language } \\
\text { according to their understanding about } \\
\text { top and tail game, then continue propose } \\
\text { examples of top and tail game in English }\end{array}$ & $\begin{array}{l}\text { Introduces the students about the game. } \\
\text { Gives examples of top and tail game in } \\
\text { their mother language, then after the } \\
\text { students understand, continue to the } \\
\text { examples in English. }\end{array}$ \\
\hline Knowing & $\begin{array}{l}\text { Try the game. The students may use } \\
\text { dictionary and handout or everything to } \\
\text { enrich their vocabulary. }\end{array}$ & $\begin{array}{l}\text { Help the students in trying the game } \\
\text { and also the vocabulary which is unfa- } \\
\text { miliar for the students. }\end{array}$ \\
\hline Practicing & $\begin{array}{l}\text { Practice top and tail game. The students } \\
\text { devided into small group. Each group } \\
\text { have to mention the word as much as } \\
\text { possible in } 5 \text { minutes. and then each } \\
\text { group write in the white board/black } \\
\text { board. The group can make words many } \\
\text { as possible within five minutes will be the } \\
\text { winner. }\end{array}$ & $\begin{array}{l}\text { Facilitates the students if they have any } \\
\text { questions in doing their practicing step. }\end{array}$ \\
\hline
\end{tabular}


the researcher concludes that using top and tail game is one way of improving students' vocabulary since vocabulary is one of the most important components in a language. The technique that the writer uses here is top and tail game, using this game is a simple technique in improving students' vocabulary since the game is easy to play and also cheap, because the teacher does not have to prepare anything or buy some equipment related to the game, just clap their hands and mention the word, also they can practice the game anywhere and with any whom. The results showed that the use of top and tail game could improve the students' vocabulary mastery. Considering the results, some suggestions are given to the English teacher, and the other researchers. The teacher suggested that they used the game as an alternative strategy to improve the students' vocabulary mastery. Future reseachers are recomended that they study the applicability of the games for students of other grades with other topics too.

\section{References}

Agoestyawati, R .(2007). 102 English games. Jakarta: Gramedia Pustaka Utama.

Arikunto, S. (2005). Dasar-dasar Evaluasi Pendidikan. Rineka Cipta: Jakarta.

Cameron, L. (2001). Teaching Language to Young Learners. Cambridge: Cambridge University Press.

Harmer, J. (2001). The practice of English Language Teaching: Longman Handbook for Language Teacher. New York: Longman Publishing

Hornby, AS. (2000). Oxford advanced learners' dictionary of current English, sixth edition. New York: Oxford University press.

Kridalaksana, H. (2008). Kamus linguistik. Jakarta: PT. Gramedia Pustaka.

Saraswati, R.M. (2014). The Effectiveness of Using Games to Improve Students' Vocabulary.
Unpublished thesis. Universitas Islam Negeri Syarif Hidayatullah, Jakarta.

Thornbury, S. (2002). How to Teach Vocabulary. England: Pearson Education Limited.

Uberman, A. (1998). The Use of Games for Vocabulary Presentation and Revision. 